\title{
SOLAR POWER FED ADJUSTUABLE SPEED DRIVE SYSTEM
}

\author{
B.Madan lal ${ }^{1}$, U.Raja Kiran' ${ }^{2}$, Sushma Gupta ${ }^{3}$, Savita Nema ${ }^{4}$ \\ ${ }^{I}$ M.Tech scholar, Department of Electrical Engineering, MANIT, Bhopal, India \\ ${ }^{2}$ M.Tech scholar, Department of Electrical Engineering, MANIT, Bhopal, India \\ ${ }^{3}$ Professor, Department of Electrical Engineering, MANIT, Bhopal, India \\ ${ }^{4}$ Professor, Department of Electrical Engineering, MANIT, Bhopal, India
}

\begin{abstract}
The conventional energy resources are widely used in power generation but they are environmentally unfriendly. The use of renewable energy resources is an alternative solution for overcoming the global warming. Solar energy has significant potential among all the renewable energy resources. As photo voltaic array has low configurable efficiency, by tracking the maximum power point by means of boost converter we can get maximum DC power. In this paper, Maximum power point Tracking (MPPT) is used by boost converter and its output is fed to the inverter for adjustable speed drive (ASD) system. The gate pulses of inverter are generated by the variable voltage and frequency control of induction motor. The developed model is simulated in MATLAB/SIMULINK.
\end{abstract}

Keywords: Adjustable speed drive, MPPT, Renewable energy, $V / f$ control.

\section{INTRODUCTION}

The power generation from conventional energy resources like coal, gas, petrol, etc raises environmental concerns, which leads to global warming. A movement towards the generation of renewable energy resources like biogas, geothermal, solar, wind, etc; is therefore solution to reduce greenhouse gas emissions globally. Solar energy has a significant potential among all the renewable energy resources. The main applications of solar energy are photo voltaic, solar heating, solar cookers and food processors, solar thermal electricity, satellites, etc. In industries they are used for ASD's, dryers, chilling, electrification, electric furnace, steam processing, water pumping, etc. The advantages of photovoltaic are low maintenance, provides cost effective electricity for remote areas, long life [1].

The ASD plays a vital role in industries [8-12]. The main purpose to vary the speed with standard induction motor is to improve process control and saving of energy. Its advantages are longer life, high efficiency, high starting torque with suitable wide range of applications, low cost and maintenance, and simple to reverse the direction of rotation.

In this paper, the developed model has two stages, as shown in figure 1. In the first stage, DC supply to inverter was fed from the solar panel; the maximum power was tracked by means of boost converter. In the second stage, the speed of the induction machine is controlled by the volts/hertz (V/f) control. The paper is organized as follows, section II presents about the MPPT based solar power module, section III discusses about ASD control scheme. Section IV presents the simulation model and results of developed system, finally section $\mathrm{V}$ concludes the solar power fed ASD system with its applications.

\section{MPPT BASED SOLAR POWER MODULE}

The MPPT based solar power module has three main parts; namely PV array, controller (MPPT), and boost converter.

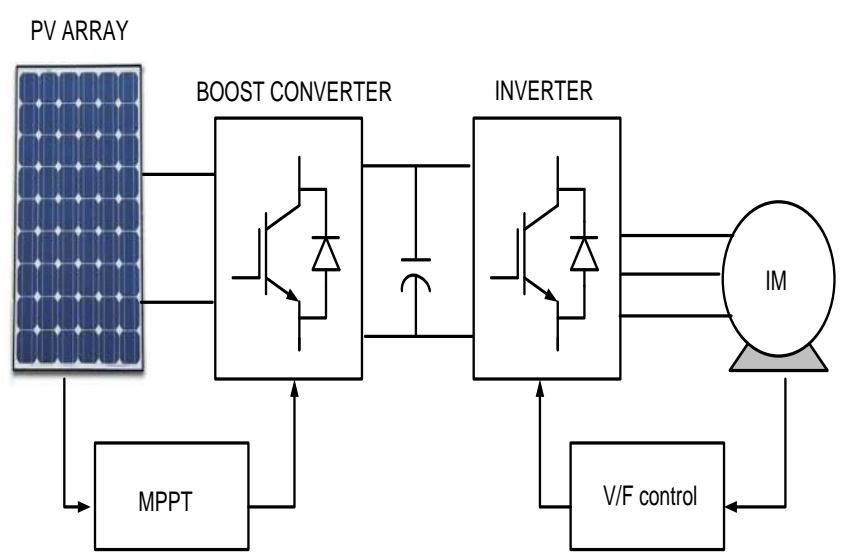

Fig.1. Block diagram of solar power fed ASD system

The modeling of PV array is given in [5] and its V-I characteristics equation is given by,

$$
I=I_{s c}-I_{o}\left\{e^{\left[q\left(\frac{v+R_{s} I}{n k T_{k}}\right)\right]}-I\right\}-\left(\left(v+R_{s} I\right) / R_{s h}\right)
$$

Where,

$\mathrm{V}$ and I represent the output voltage and current of the PV, respectively. 
$\mathrm{R}_{\mathrm{s}}$ and $\mathrm{R}_{\mathrm{sh}}$ are the series and shunt resistance of the cell.

$\mathrm{q}$ is the electronic charge.

$\mathrm{I}_{\mathrm{SC}}$ is the light-generated current.

$I_{0}$ is the reverse saturation current.

$\mathrm{n}$ is a dimensionless factor.

$\mathrm{k}$ is the Boltzman constant, and

$\mathrm{T}_{\mathrm{k}}$ is the temperature in ${ }^{\circ} \mathrm{K}$.

MPPT is algorithm that includes in charge controllers used for extract maximum available power from PV model under certain considerations. The voltage at which maximum has tracked is called MPPT point. It varies with ambient temperature, radiation and solar cell temperature. The main different types of MPPT algorithms available are perturb and observe ( $\mathrm{P} \& \mathrm{O})$, incremental conductance (INC), current shift method, and constant voltage [2,3]. There some special algorithms based on fuzzy, neural networks, PSO and pilot cells [6,7]. In spite of these, $\mathrm{P} \& \mathrm{O}$ and INC techniques are mostly used for low cost implementation. Maximum power is tracked by periodically incrementing and decrementing the PV array voltage. If a given perturbation results in increase/decrease output power of $\mathrm{PV}$, then the subsequent perturbation is generated in same/opposite direction [4].

Figure 2 flowchart shows the $\mathrm{P} \& \mathrm{O}$ algorithm technique

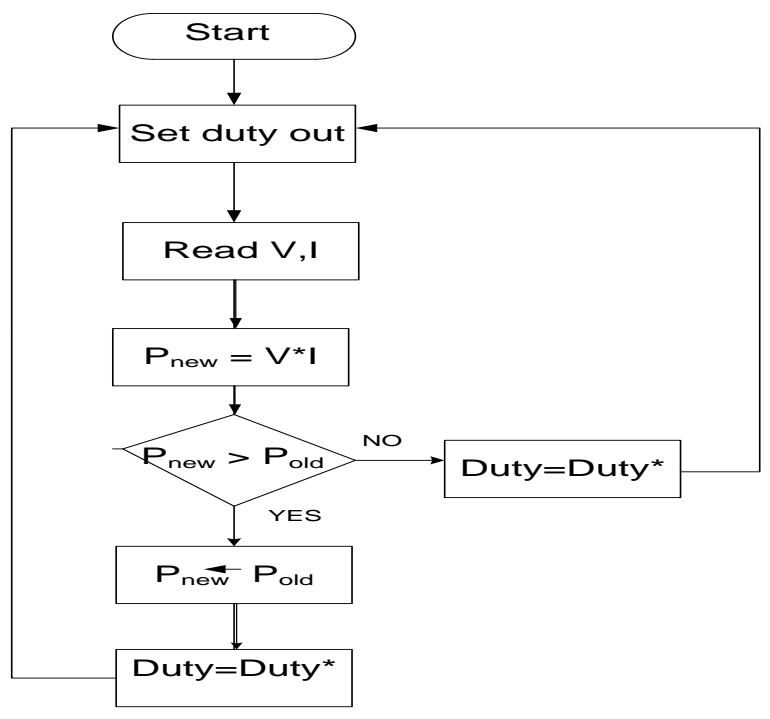

Fig.2 Flow chart of $\mathrm{P} \& \mathrm{O}$ algorithm

The boost converter is used to boost up the DC voltage of PV array to the DC link of inverter. The duty ratio is set by the MPPT. The boost converter topology and its waveforms are shown in figure 3.

The equations of boost converter are given by,

$$
V_{\text {out }}=(1 /(1-\delta)) * V_{\text {in }}
$$

$$
\begin{gathered}
\delta=t_{\text {on }} / T \\
T=\left(t_{\text {on }}+t_{\text {off }}\right)
\end{gathered}
$$

Where,

$\mathrm{V}_{\text {in }}$ and $\mathrm{V}_{\text {out }}$ are the input and output voltage of boost converter respectively

$\mathrm{T}$ is time period of pulse
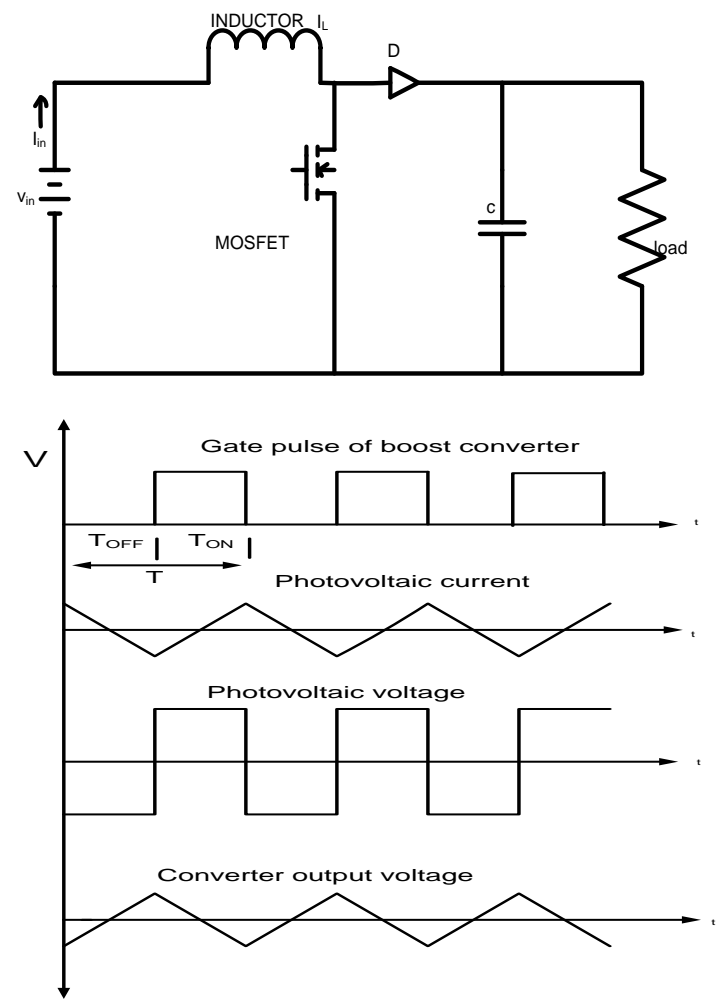

Fig.3 Boost converter circuit and its wave forms

\section{ADJUSTABLE SPEED DRIVE SYSTEM}

The main parts of ASD system are three phase inverter, induction motor, and controller. The block diagram of speed control of induction motor (ASD system) is shown in figure 4. The inverter is a conventional three leg IGBT module connected with squirrel cage induction motor. The controller used here is a closed loop V/f control. As the flux is proportional to the ratio of voltage and frequency, when the voltage is kept as constant and frequency is decreased, IM draws more magnetizing current which leads to deep saturation. If frequency is kept constant and increase the supply voltage to motor leads to insulation failure. So always V/f should be maintained constant In the closed loop control, the actual speed is compared with the reference speed and then the error is processed by PI controller. The PI output is used to create reference signal for generating sinusoidal pulse width modulation (SPWM) pulses to the inverter. 


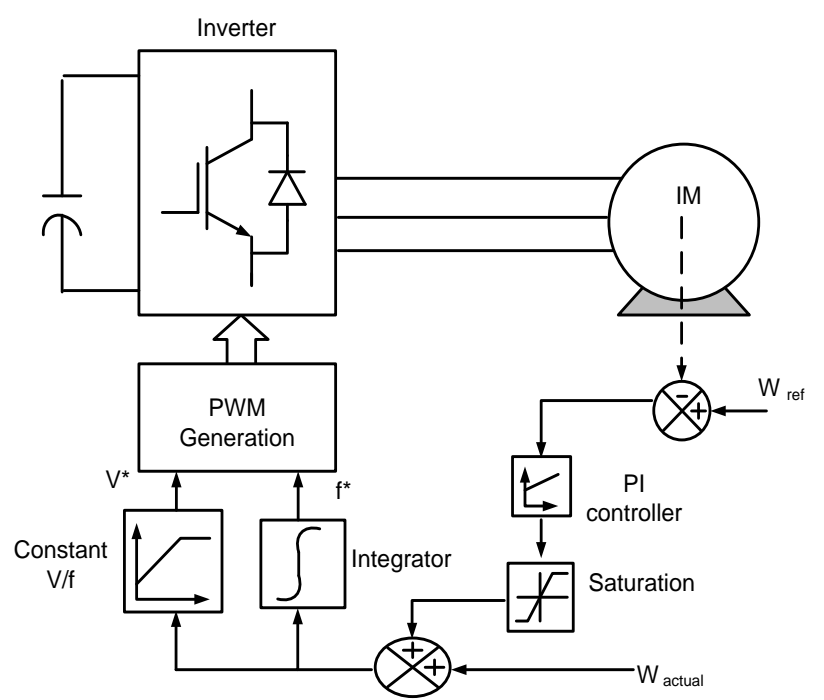

Fig.4 Block diagram of speed control of Induction motor (ASD system)

\section{SIMULATION MODEL AND RESULTS}

The simulation model of solar power fed ASD system is shown in figure 5.

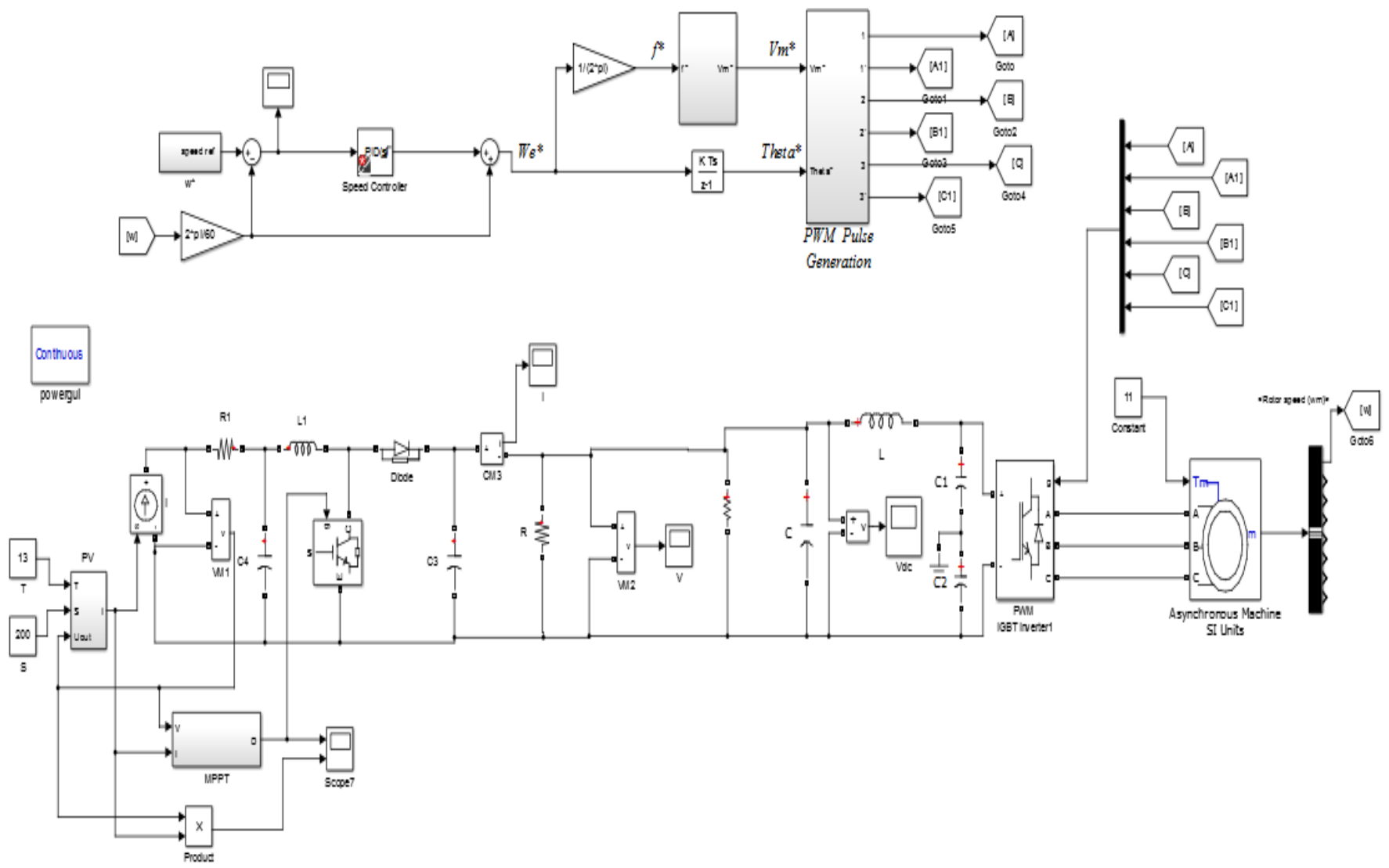

Fig.5. Simulink model of solar power fed ASD system 
The output voltage, current, power waveforms of PV array is shown in figures 6,7 and 8 respectively.

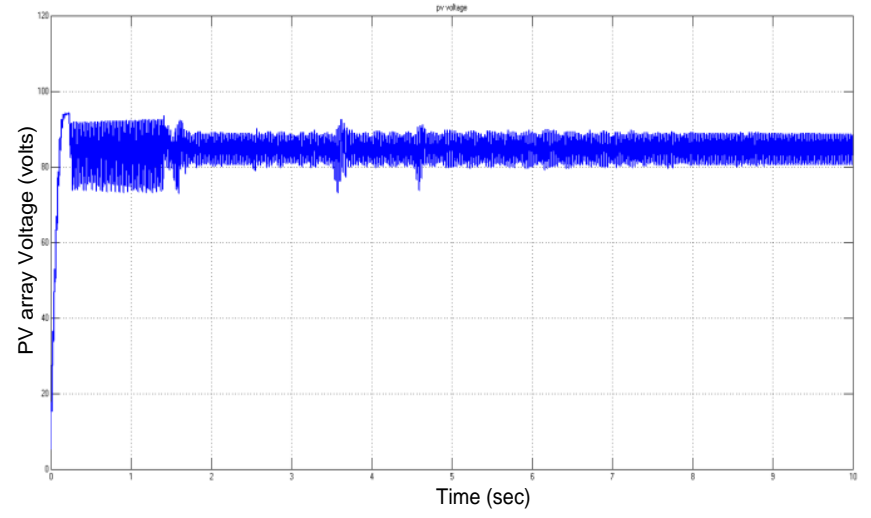

Fig.6 PV array output Voltage waveform

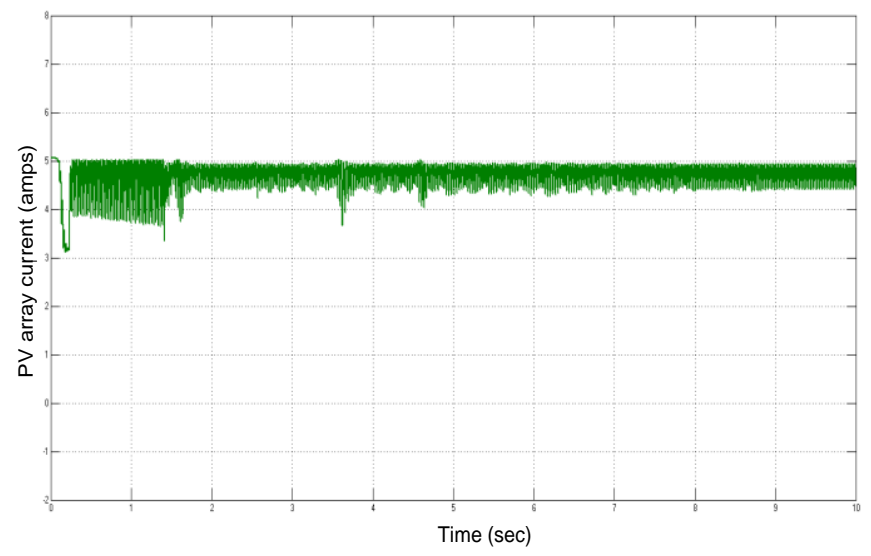

Fig.7 PV array output current waveform

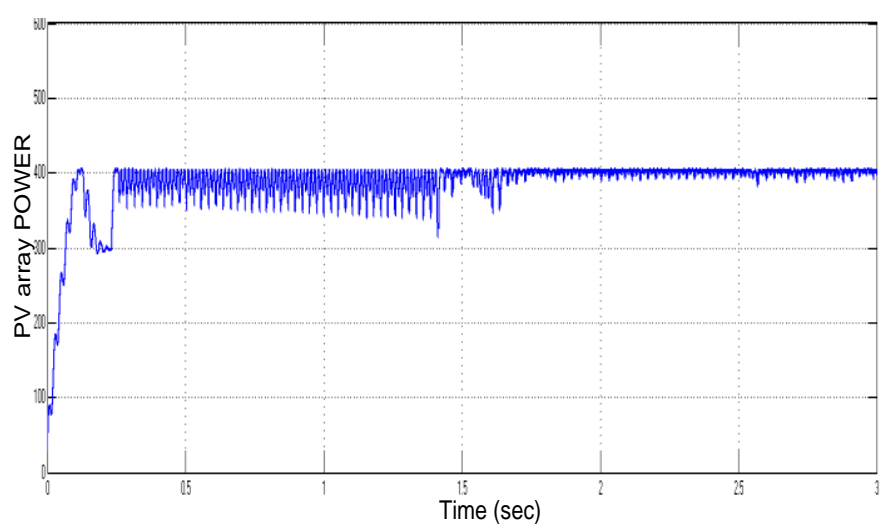

Fig.8 PV array output power waveform

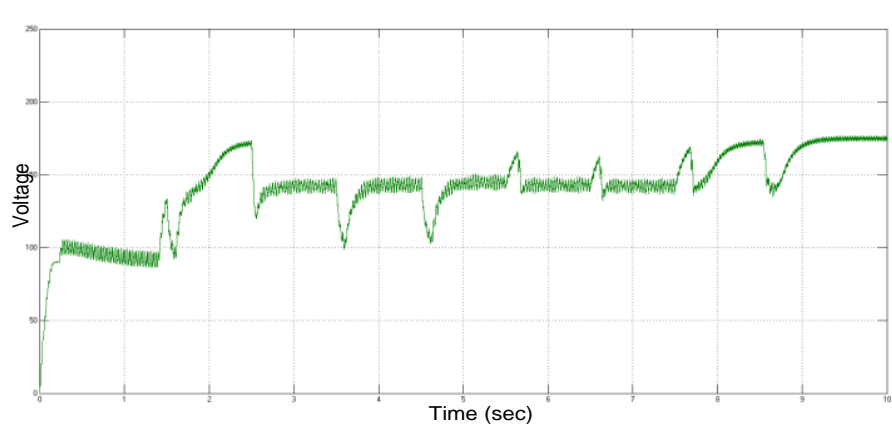

Fig. 9 Boost converter output voltage waveform

The speed response and torque developed by the solar power fed ASD system are shown in figure 10 and 11.

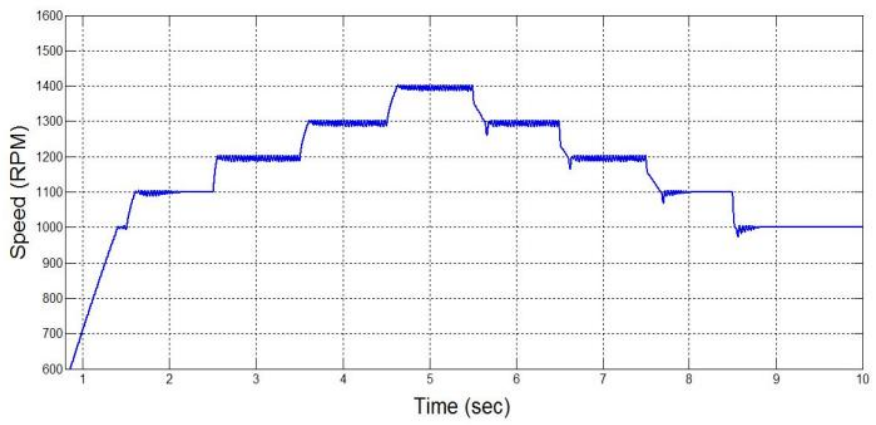

Fig.10 Step size speed control of solar power fed ASD system

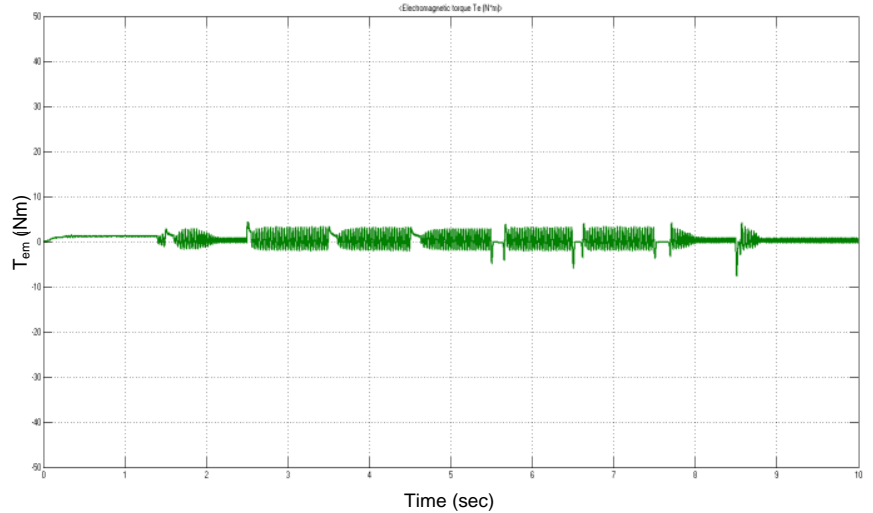

Fig.11 Electromagnetic Torque developed by solar power fed ASD system

The step size speed control of induction motor shows the characteristics of ASD system. Thus by this response the solar power fed ASD system is applicable in HVAC, fans and water pumps, food processing, petro chemicals, Mining and metals, pulp and paper/forest producers, machine tools, transportation. 


\section{CONCLUSIONS}

The solar power fed adjustable speed drive system has been simulated in MATLAB/SIMULINK and its results are discussed. As the solar has significant potential among all the renewable energy resources, solar power modules should be installed in domestic and industries for electrification or various applications which are listed. By utilizing solar power for ASD system, reduces losses, reduces power supply problems, reduces motor heating and stress, increases efficiency, high saving in energy, low maintenance, long life and improves the process of control. Thus the developed model is robust and energy saving system.

\section{REFERENCES}

[1] Joe-Air Jiang,Tsong-Liang Huang, Ying-Tung Hsiao and Chia-Hong Chen, "Maximum Power Tracking for Photovoltaic Power Systems," Tamkang Journal of Science and Engineering, Vol. 8, No 2, pp. 147-153, 2005

[2] Elgendy M. A, Zahawi, B and Atkinson D. J, "Evaluation of perturb and observe MPPT algorithm implementation techniques," IET International Conference on Power Electronics, Machines and Drives, 2012

[3] A. Chouder, F. Guijoan and S. Silvestre, "Simulation of fuzzy-based MPP tracker and performance comparison with perturb \&observe methodll," Revue des Energies Renouvelables Vol. 11, No. 4, pp. 577586, 2008

[4] Nicola Femia, Giovanni Petrone, Giovanni Spagnuolo and Massimo Vitelli, "Optimization of Perturb and Observe Maximum Power Point Tracking Method," IEEE Transactions on Power Electronics, Vol. 20, No. 4, 2005

[5] Savita Nema, R.K. Nema, Gayatri Agnihotri, "MATLAB/Simulink based study of photovoltaic cells / modules / array and their experimental verification", International journal of Energy and Environment, vol.1, No.3, pp.487-500, 2010.

[6] Bidyadhar subudhi and raseswari Pradhan,"A Comparative study on Maximum Power PointTracking Techniques for Photovoltaic Power Systems," IEEE Transactions On Sustainable Energy, Vol. 4, No. 1, JANUARY 2013.

[7] Esram $\mathrm{T}$ and Chapman $\mathrm{P}$ L, "Comparison of Photovoltaic Array Maximum Power Point Tracking Techniques," IEEE Transactions on Energy Conversion, , vol.22, no.2, pp.439-449, June 2007.

[8] Bimal Bose, "Induction Motor Drives," in Power Electronics and Motor Drives Advances and Trends, Academic Press publications, 2006, pp.391-476

[9] Bose, B.K., "High performance control and estimation in AC drives," 23rd International Conference on Industrial Electronics, Control and Instrumentation
(IECON 97), vol.2, no., pp.377,385 vol.2, 9-14 Nov 1997

[10] Bazzi A.M and Krein P T., "Review of Methods for Real-Time Loss Minimization in Induction Machines," IEEE Transactions on Industry Applications, vol.46, no.6, pp.2319,2328, Nov.-Dec. 2010.

[11] Nafisa Binte Yousuf, Khosru M. Salim, Rafid Haider, Md. Rajin Alam, Fatima Binte Zia "Development of a Three Phase Induction Motor Controller for Solar Powered Water Pump" IEEE Trans. Power Electron., vol. 24, no. 5, pp. 1198-1208, May 2009.

[12] Nejib Hamrouni, Moncef Jraidi and Adnene Cherif, "Theoretical and experimental analysis of the behaviour of a photovoltaic pumping system," Solar Energy 83(2009), pp. 335-1344, 2009 